\title{
Novel treatments for rare rheumatologic disorders: analysis of the impact of 30 years of the US orphan drug act
}

\author{
Thomas Lutz ${ }^{1 \dagger}$, Anette Lampert ${ }^{2,3 \dagger}$, Georg F. Hoffmann ${ }^{4}$ and Markus Ries ${ }^{4 *}$
}

\begin{abstract}
Background: Rare rheumatologic diseases are a heterogeneous group of conditions associated with high morbidity. As a whole group, rare rheumatologic diseases afflict millions of people demanding for effective therapies. Therefore, we analyzed the impact of the US Orphan Drug Act on the development of anti-rheumatic orphan drugs.

Methods: Analysis of the FDA database for orphan drug designations.

Results: In the last three decades, out of 77 orphan drug designations, 14 orphan drug approvals were granted by the FDA for the treatment of rare rheumatologic disorders, i.e. juvenile idiopathic arthritis $(N=5)$, cryopyrinassociated periodic syndromes $(N=3)$, uveitis $(N=3)$, familial Mediterranean fever $(N=1)$, anti-neutrophil cytoplasmic antibody-associated vasculitis $(N=1)$, and xerostomia and keratoconjunctivitis sicca in Sjögren's syndrome $(N=1)$. Mean time (standard deviation) from designation to approval was 3.9 (2.81) [range $1 \ldots 12$ ] years. Number of FDA-approved small molecules $(N=6,43 \%)$ and biologics $(N=8,57 \%)$ was comparable. Almost every fifth (19\%) orphan drug designation was withdrawn. Despite the rarity of conditions, 13/14 pivotal studies were randomized controlled trials.

Conclusions: Orphan drug development is challenging: thirty years of US orphan drug act supported the development and FDA approval of 14 orphan drug programs with anti-rheumatic compounds for six rheumatologic diseases.
\end{abstract}

Keywords: Orphan drug act, Orphan drug development, Rare disease, Rare rheumatologic disease

\section{Background}

Rheumatologic diseases are associated with high morbidity leading to reduced quality of life, potentially life-long disability, and premature death. Although rare in individuals, as a whole group rare rheumatologic disorders afflict a large group of people $[1,2]$. Furthermore, many rare autoinflammatory conditions, such as systemic lupus erythematodes, dermatomyositis, scleroderma, vasculitis, periodic fever syndromes, nonbacterial osteomyelitis, or uveitis can

\footnotetext{
* Correspondence: markus.ries@uni-heidelberg.de

${ }^{\dagger}$ Equal contributors

${ }^{4}$ Center for Pediatric and Adolescent Medicine/Pediatric Neurology and Metabolic Medicine, Center for Rare Disorders, Heidelberg University Hospital, Im Neuenheimer Feld 430, D-69120 Heidelberg, Germany

Full list of author information is available at the end of the article
}

manifest already in childhood. For example, the prevalence of juvenile idiopathic arthritis (JIA), having its onset before 16 years of age, varies between 3.8 and 400 per 100,000 $[1,3]$. Considering the definition for an orphan disease in general as a condition affecting less than 7.5 people in 10.000 or less than 200.000 in the US or less than five in 10.000 in the European Union, orphan drug development is tremendously challenged by small sample sizes $[2,4,5]$. In addition, highly variable manifestations of rheumatologic diseases and onset in childhood complicate drug development. The US Orphan Drug Act was passed in 1983 to stimulate the investment into development of treatments for rare diseases by granting various incentives, such as 7 years' marketing exclusivity, tax credit for $50 \%$ of clinical trial costs, protocol assistance, Food and Drug Administration (FDA) fee waiver, and orphan grants 
programs [4]. The impact of the US orphan drug act on successful drug development for the treatment of rare rheumatologic diseases has not been systematically analyzed. We therefore analyzed how many orphan drugs were designated and subsequently approved by the FDA between 1983 and 2013 to treat rare rheumatologic diseases.

\section{Methods}

\section{Search strategy}

For quantitative analysis, we searched the publically available FDA database for orphan drug designations [6] using the following disease entities as search terms (terms for pediatric rheumatologic diseases in alphabetical order [7]): arthritis, antiphospholipid antibody syndrome, Behçet syndrome, collagenosis, CREST syndrome (calcinosis, Raynaud's phenomenon, esophageal dysmotility, sclerodactyly and telangiectasia), childhood and adolescence arthritis, CAPS (cryopyrin-associated periodic syndromes) such as CINCA/NOMID (chronic infantile neurologic cutaneous and articular syndrome/neonatal-onset multisystem inflammatory disease), MWS (Muckle-Wells syndrome) or FCAS (familial cold autoinflammatory syndrome), cutaneous leukocytoclastic vasculitis, dermatomyositis, diffuse sclerosis, drug induced lupus erythematosus, enthesitis-related arthritis, eosinophilic fasciitis (Shulman syndrome), eosinophilic granulomatosis with polyangiitis (Churg-Strauss syndrome), familial cold autoinflammatory syndrome, familial Mediterranean fever, Felty syndrome, granulomatosis with polyangiitis, Hyper IgD syndrome, idiopathic uveitis, IgA vasculitis (Henoch Schönlein purpura), infantile sarcoidosis, isolated sacroiliitis, juvenile ankylosing spondylitis, juvenile idiopathic arthritis, Kawasaki syndrome, limited systemic sclerodermia, localized scleroderma, lupus, microscopic polyangiitis, mixed connective tissue disease, non-bacterial osteitis, oligoarthritis, periodic fever syndromes, PFAPA syndrome (periodic fever, aphthous stomatitis, pharyngitis, adenitis), polyarteritis nodosa, polymyositis, primary angiitis of the central nervous system, psoriatic arthritis, relapsing polychronditis, rheumatoid factor negative polyarthritis, rheumatoid factor positive polyarthritis, Sharp syndrome, Sjögren's syndrome, spondyloarthritis due to chronic inflammatory intestinal disorders, spondyloarthritis due to psoriasis, spondylodiscitis, spondylolisthesis, spondylolysis, systemic arthritis, systemic lupus erythematosus, systemic sclerosis, Takayasu arteritis, transient synovitis, TRAPS (tumor necrosis factor receptor associated periodic syndrome), undifferentiated juvenile idiopathic arthritis, and vasculitis (e.g., Anti-neutrophil cytoplasmic antibody (ANCA) associated vasculitis). Non-English alphabet letters such as umlaut were searched with alternative spellings (e.g., $\ddot{o}$ was also entered as both o and oe). Acronyms were searched by both the acronym and the full wording. Disease terms with more than one word were searched with the full disease term and with each individual component of the term, e.g., "juvenile idiopathic arthritis" was searched as "juvenile", "idiopathic", "arthritis", and "juvenile idiopathic arthritis". All search results were subsequently checked for plausibility. All data entries from 1/1/1983 until 12/31/2013 were considered. Original terms from the FDA orphan drug database or FDA label were used to describe designated or approved indications to conform to source data.

\section{Definitions}

Identified compounds were categorized either according to their drug class or pharmacologic category. Within the respective classification, remaining compounds that could not be clearly allocated to a particular category were grouped as others. For classification according to their drug class, the compounds were accounted as small molecules or biologics. A small molecule was defined as a low-weight molecule (typically $<1,000 \mathrm{Da}$ ) which is usually derived from chemical synthesis and can be fully characterized by analytical techniques [8, 9]. In contrast, biologics are large-molecular weight and structurally complex proteins that are derived from living cells through biotechnological processes (e.g., antibody methods, controlled gene expression or recombinant DNA) $[8,9]$. Biologics were further differentiated into antibodies and fusion proteins. For classification according to pharmacologic category, compounds were grouped according to their mechanism of action which was gained from the FDA label for approved compounds. For the assessment of the putative mechanism of action of compounds that were not approved by the FDA, we started from the designated indication and selected the most likely mechanism of action causing the intended effect.

\section{Statistics}

Data were analyzed by standard methods of descriptive statistics with SAS Enterprise Guide version 5.1 (SAS, Cary, NC, USA). Continuous variables are presented as means, standard deviations, and ranges. For categorical variables, $\mathrm{N}$ and percentages were calculated. Time-toapproval was calculated as the time span from orphan drug designation to FDA approval.

\section{Results}

\section{Orphan drug designations}

Overall, 77 orphan drug designations were granted for 64 different compounds between 1983 and 2013 (Fig. 1, Table 1). The first orphan drug designations were granted in 1986 for two compounds, i.e. guanethidine monosulfate (for the treatment of moderate to severe reflex sympathetic dystrophy and causalgia) and dimethyl sulfoxide (for the treatment of cutaneous manifestations of scleroderma). 


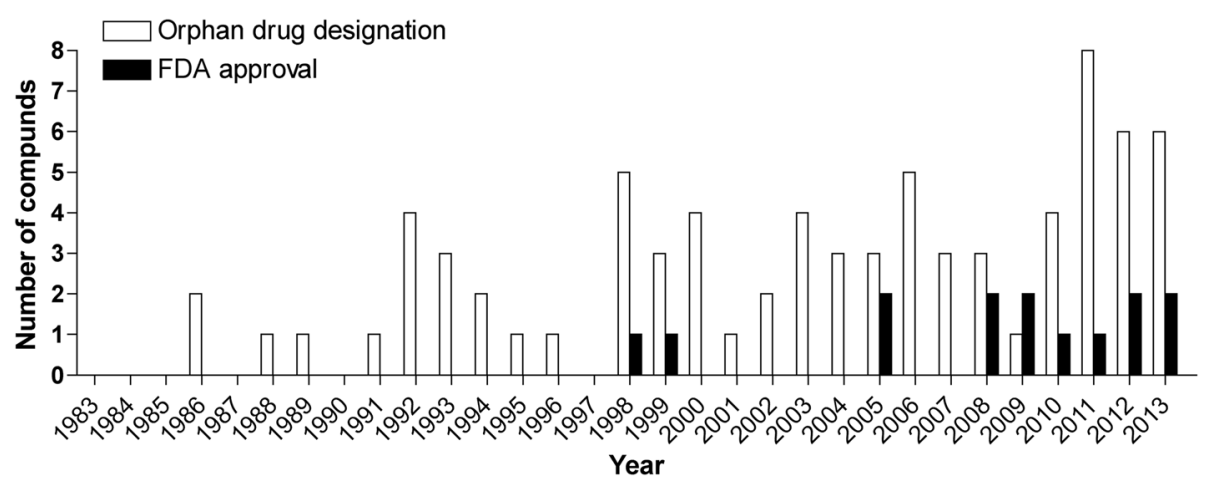

Fig. 1 Orphan drugs for rare rheumatologic disorders - number of orphan drug designations (open box) and FDA approvals (black box) per year

Both designations were subsequently withdrawn. Most designations per year were granted in $2011(N=8)$. When analyzed according to drug classes, 33/77 (43\%) designations were granted for 23 different biologics, 28/77 (36 \%) for 27 different small molecules and 14/77 (18 \%) designations for others representing 12 different compounds (Table 1). With two designations the drug class of the compounds was unknown (i.e., AI-RSA and Interleukin-1 Trap). Biologics were further differentiated into chimeric antibodies (4/33), human antibodies (10/33), humanized antibodies (8/33), unspecified antibodies (2/33) (i.e., human anti-tumor necrosis factor alpha monoclonal antibody and monoclonal antibody for immunization against lupus nephritis), fusion proteins (4/33), and other biologics (5/33) (i.e., anakinra, hanferon, interferon beta-1a, interleukin-1 receptor antagonist human recombinant, and a DNA plasmid pVGI.1 (VEGF2)) (Fig. 2).

\section{FDA approvals}

Between 1983 and 2013, 14/77 (18 \%) orphan drug designations received FDA approval representing 13 different compounds, because canakinumab was approved for two indications (Table 2, Fig. 1). Five drugs were approved for JIA, three for CAPS, three for uveitis, one for familial Mediterranean fever, one for ANCA associated vasculitis, and one for xerostomia and keratoconjunctivitis sicca in Sjögren's syndrome patients (Table 2). The first approved orphan compound for a rare rheumatologic condition was pilocarpine hydrochloride for treating xerostomia and keratoconjunctivitis in Sjögren's syndrome in 1998. Mean time (standard deviation) from designation to approval was 3.9 (2.81) [range 1 ... 12] years. Divided according to drug classes, 6/14 (43\%) FDA orphan drug approvals comprised small molecules and 8/14 (57 \%) FDA orphan drug approvals were biologics. The time between orphan drug designation and time of approval was similar for biologics and small molecules (Fig. 3). Most pivotal trials were randomized controlled trials (Table 2).

\section{Withdrawn orphan drug designations}

Overall, 15/77 (19\%) orphan drug designations (14 compounds) were withdrawn before approval (Table 3). The reasons for withdrawals were not captured in the FDA database.

\section{Pharmacologic categories of designated orphan drugs}

Designated compounds were immunomodulators, such as immunosuppressants, immunostimulants, tolerogens, or compounds with unspecified immunomodulatory properties, Nonsteroidal anti-inflammatory drugs (NSAIDs), expectorants, antibiotics, and angiogenic, antiarrhythmic, diagnostic, parasympathomimetic, and sympatholytic agents.

\section{Design of pivotal clinical trials and endpoints leading to FDA approval}

Only one pivotal trial, i.e. the study of anakinra for the treatment of neonatal onset inflammatory disease, was open label (Table 2). The other 12 approved compounds were studied for 13 indications in randomized controlled trials in which withdrawal designs were common. Colchicine received approval for the treatment of familial Mediterranean fever based on data available in the published literature. Most clinical trials were rather small and involved both children and adults. Studies were either uncontrolled (i.e., anakinra) or controlled with placebo (i.e., colchicine, rilonacept, canakinumab in both indications, etanercept, pilocarpine, adalimumab, and tocilizumab), sham procedure (i.e., dexamethasone intravitreal implant), before after control (i.e., fluocinolone acetonide intravitreal implant), or active control (i.e., meloxicam vs. naproxen, difluprednate ophthalmic solution vs. prednisolone, rituximab vs. cyclophosphamide in a non-inferiority design). Etanercept was studied as addon therapy to an NSAID and/or prednisone.

\section{Discussion}

In 2013, 77 orphan drug designations for rare rheumatologic disorders were granted by the FDA whereof 
Table 1 Drug class and indications of designated anti-rheumatic orphan drugs

\begin{tabular}{|c|c|c|}
\hline Drug class & Compound & Designated indication according to FDA database \\
\hline \multicolumn{3}{|l|}{ Biologic } \\
\hline \multirow[t]{2}{*}{ Chimeric monoclonal antibody } & Infliximab & $\begin{array}{l}\text { Treatment of juvenile rheumatoid arthritis. } \\
\text { Treatment of giant cell arteritis. } \\
\text { Treatment of chronic sarcoidosis. }\end{array}$ \\
\hline & Rituximab & $\begin{array}{l}\text { For the use in combination with glucocorticoids for the } \\
\text { treatment of patients with Wegener's granulomatosis (WG) } \\
\text { and microscopic polyangiitis (MPA). }\end{array}$ \\
\hline \multirow[t]{5}{*}{ Human monoclonal antibody } & Adalimumab & Treatment of juvenile rheumatoid arthritis. \\
\hline & Canakinumab & $\begin{array}{l}\text { Treatment of pediatric (age } 16 \text { and under) juvenile } \\
\text { rheumatoid arthritis. } \\
\text { Treatment of cryopyrin-associated periodic syndromes. } \\
\text { Treatment of Tumor Necrosis Factor-receptor associated } \\
\text { periodic syndrome (TRAPS). } \\
\text { Treatment of hyperimmunoglobulinemia D and periodic } \\
\text { fever syndrome. } \\
\text { Treatment of familial mediterranean fever. }\end{array}$ \\
\hline & Golimumab & $\begin{array}{l}\text { Treatment of chronic sarcoidosis. } \\
\text { Treatment of sarcoidosis. }\end{array}$ \\
\hline & Secukinumab & $\begin{array}{l}\text { Adjunctive treatment of chronic non-infectious uveitis } \\
\text { requiring systemic immunosuppression. }\end{array}$ \\
\hline & Ustekinumab & Treatment of chronic sarcoidosis. \\
\hline \multirow[t]{7}{*}{ Humanized monoclonal antibody } & Eculizumab & Treatment of dermatomyositis. \\
\hline & Gevokizumab & $\begin{array}{l}\text { Treatment of Behçet disease. } \\
\text { Treatment of non-infectious intermediate, posterior or pan } \\
\text { uveitis, or chronic non-infectious anterior uveitis. }\end{array}$ \\
\hline & $\begin{array}{l}\text { Humanized monoclonal antibody } \\
\text { to CD40L (IDEC-131) }\end{array}$ & Treatment of systemic lupus erythematosus. \\
\hline & $\begin{array}{l}\text { Humanized, afucosylated lgG1 kappa } \\
\text { monoclonal antibody }\end{array}$ & Treatment of scleroderma. \\
\hline & Mepolizumab & Treatment of Churg-Strauss Syndrome. \\
\hline & $\begin{array}{l}\text { Recombinant humanized monoclonal } \\
\text { antibody } 5 \mathrm{c} 8\end{array}$ & Treatment of systemic lupus erythematosus. \\
\hline & Tocilizumab & $\begin{array}{l}\text { Treatment of pediatric patients (age } 16 \text { years and younger) } \\
\text { with polyarticular-course juvenile idiopathic arthritis. }\end{array}$ \\
\hline \multirow[t]{2}{*}{ Unspecified monoclonal antibody } & $\begin{array}{l}\text { Human anti- Tumor Necrosis Factor } \\
\text { alpha monoclonal antibody }\end{array}$ & $\begin{array}{l}\text { Treatment of uveitis of the posterior segment of non- } \\
\text { infectious etiology, and uveitis of the anterior segment of } \\
\text { non-infectious etiology and refractory to conventional therapy. }\end{array}$ \\
\hline & $\begin{array}{l}\text { Monoclonal antibody for immunization } \\
\text { against lupus nephritis }\end{array}$ & Treatment of lupus nephritis. \\
\hline \multirow[t]{2}{*}{ Fusion protein } & Etanercept & $\begin{array}{l}\text { Reduction in signs and symptoms of moderately to severely } \\
\text { active polyarticular-course juvenile rheumatoid arthritis in } \\
\text { patients who have had an inadequate response to one or } \\
\text { more disease-modifying anti-rheumatic drugs. } \\
\text { Treatment of Wegener's granulomatosis. }\end{array}$ \\
\hline & Rilonacept & $\begin{array}{l}\text { Treatment of CIAS1-associated periodic syndromes. } \\
\text { Treatment of familial Mediterranean fever. }\end{array}$ \\
\hline \multirow[t]{5}{*}{ Other } & Anakinra & Treatment of cryopyrin-associated periodic syndromes. \\
\hline & Hanferon & Treatment of Behçet disease. \\
\hline & Interferon beta-1a & Treatment of juvenile rheumatoid arthritis. \\
\hline & $\begin{array}{l}\text { Interleukin-1 receptor antagonist, } \\
\text { human recombinant }\end{array}$ & Treatment of juvenile rheumatoid arthritis. \\
\hline & pVGI.1 (VEGF2) & Treatment of thromboangiitis obliterans. \\
\hline
\end{tabular}


Table 1 Drug class and indications of designated anti-rheumatic orphan drugs (Continued)

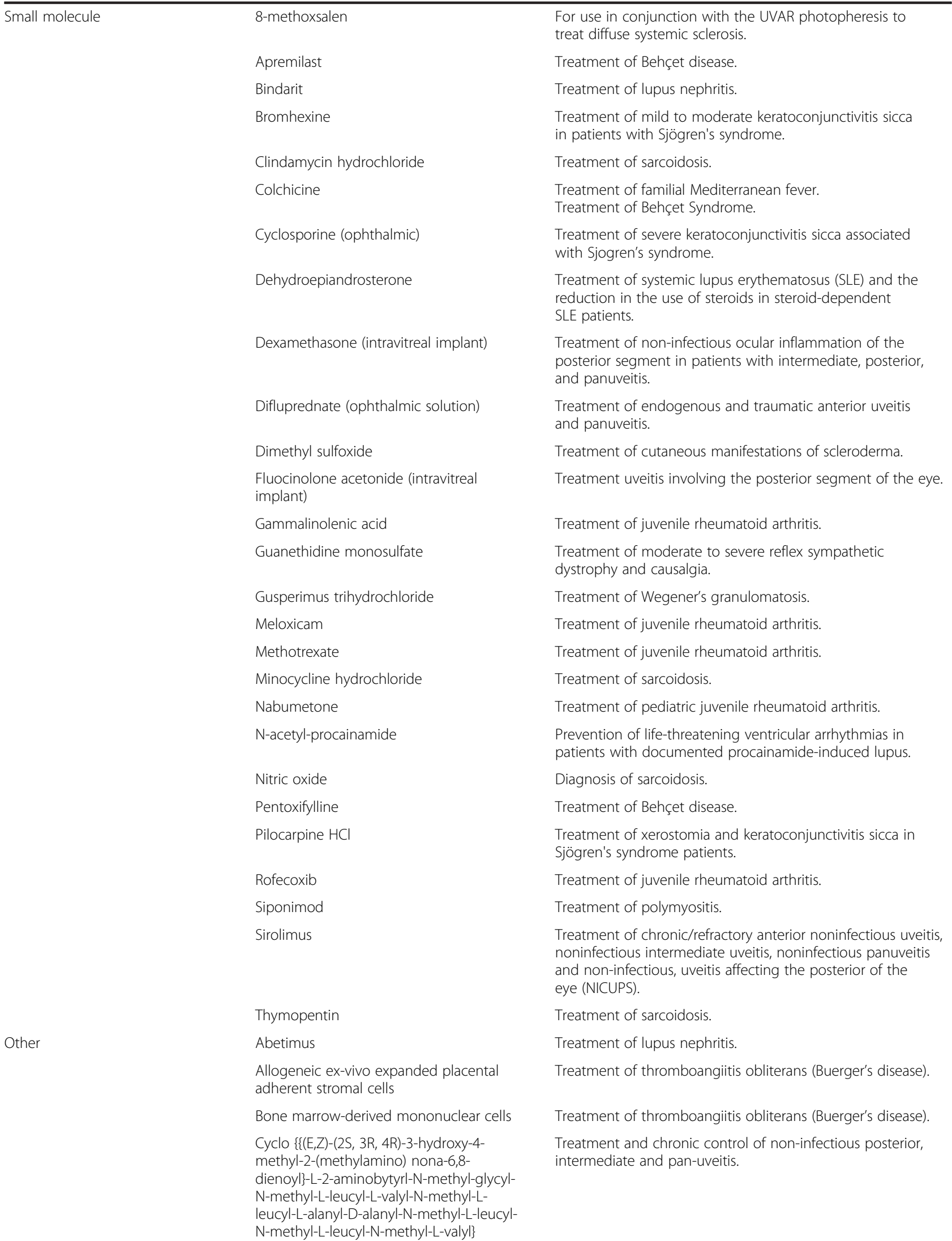


Table 1 Drug class and indications of designated anti-rheumatic orphan drugs (Continued)

\begin{tabular}{|c|c|c|}
\hline & Human gammaglobulin & $\begin{array}{l}\text { Treatment for juvenile rheumatoid arthritis. } \\
\text { Treatment of idiopathic inflammatory myopathies. }\end{array}$ \\
\hline & Immune globulin intravenous (IVIG) & $\begin{array}{l}\text { Treatment of juvenile rheumatoid arthritis. } \\
\text { Treatment of polymyositis/dermatomyositis. }\end{array}$ \\
\hline & $\begin{array}{l}\text { Kre-Celazine (Oral Buffered Creatine- } \\
\text { Cetylated Fatty Acid Compound) }\end{array}$ & $\begin{array}{l}\text { Treatment of juvenile rheumatoid arthritis joint and } \\
\text { related tissue inflammation in the pediatric population. }\end{array}$ \\
\hline & Lactobacillus brevis CD2 & Treatment Behçet disease. \\
\hline & $\begin{array}{l}\text { L-pyr-L-glu-L-gln-L-leu-L-glu-L-arg-L-ala- } \\
\text { L-leu-L-asn-L-ser-L-ser }\end{array}$ & Treatment of neuropathic pain in patients with sarcoidosis. \\
\hline & $\begin{array}{l}\text { Natural human lymphoblastoid } \\
\text { interferon-alpha }\end{array}$ & Treatment of Behçet disease. \\
\hline \multirow{4}{*}{ Unknown } & Peptide 144 (TGF beta-1-inhibitor) & Treatment of localized scleroderma. \\
\hline & Purified type II collagen & Treatment of juvenile rheumatoid arthritis. \\
\hline & Al-RSA & Treatment of autoimmune uveitis. \\
\hline & Interleukin-1 Trap & $\begin{array}{l}\text { Treatment of Still's disease including juvenile rheumatoid } \\
\text { arthritis and adult-onset Still's disease. }\end{array}$ \\
\hline
\end{tabular}

14 resulted in FDA approval comprising 13 different substances. Almost every fifth designation was withdrawn, mostly with unknown reasons. However, with etanercept safety reasons may have played a role in withdrawal: etanercept was studied in Wegener's granulomatosis with a higher incidence of malignancies observed in the etanercept group compared with standard therapy [10, 11]. The success rate to achieve marketing approval in rheumatologic orphan drug development is comparable to overall success rates in orphan drug development, i.e. 14\% [12]. In general, failure of orphan drug applications are mainly attributed to the pivotal clinical trial design (e.g. choice of endpoints and target population), inexperience in orphan drug development of sponsors, and a low level of interaction with the FDA (e.g. protocol assistance) [13]. These factors seem to be interdependent because inexperienced sponsors may choose inadequate pivotal clinical trial designs and may benefit most from FDA protocol assistance. The reasons why compounds were withdrawn or not approved e.g. lack of efficacy, safety issues or due to commercially driven decisions, are not available in the FDA database. Although, this information would be of

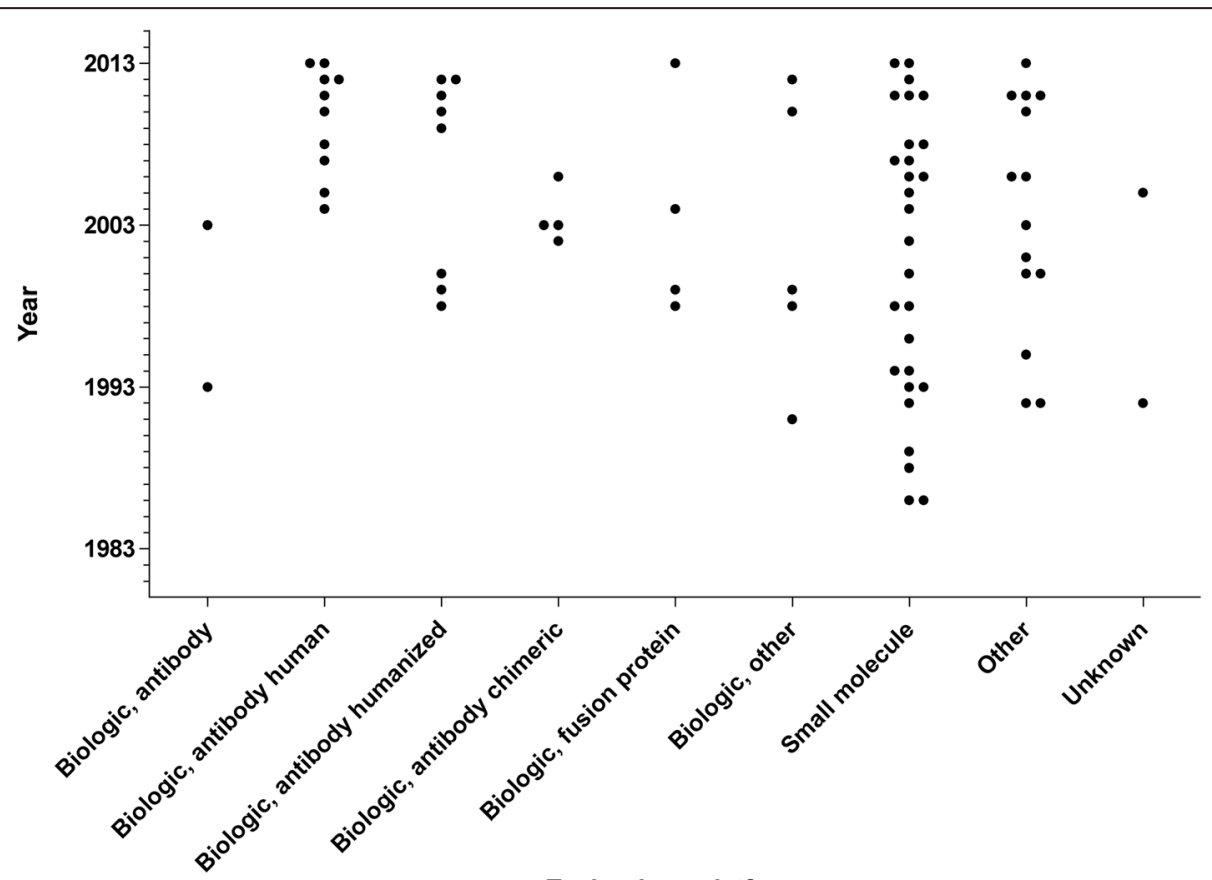

Technology platform

Fig. 2 Orphan drugs for rare rheumatologic disorders: year of orphan drug designation by technology platform 
Table 2 Orphan drugs for the treatment of rare rheumatologic disorders approved by the FDA between 1983 and 2013

\begin{tabular}{|c|c|c|c|c|c|c|c|c|c|c|}
\hline \multirow[t]{2}{*}{ Compound } & \multirow{2}{*}{$\begin{array}{l}\text { Approved indication according } \\
\text { to FDA label }\end{array}$} & \multirow{2}{*}{$\begin{array}{l}\text { Pharmacologic } \\
\text { category }\end{array}$} & \multirow{2}{*}{$\begin{array}{l}\text { Designation } \\
\text { year }\end{array}$} & \multirow{2}{*}{$\begin{array}{l}\text { Approval } \\
\text { year }\end{array}$} & \multicolumn{5}{|c|}{ Pivotal clinical trial } & \multirow[t]{2}{*}{ Reference } \\
\hline & & & & & $\begin{array}{l}\text { Study } \\
\text { design }\end{array}$ & $\mathrm{N}$ & Age & $\begin{array}{l}\text { Study } \\
\text { duration }\end{array}$ & Main outcome measure & \\
\hline \multirow[t]{2}{*}{$\begin{array}{l}\text { Pilocarpine } \\
\text { hydrochloride }\end{array}$} & \multirow[t]{2}{*}{$\begin{array}{l}\text { Treatment of dry mouth in } \\
\text { patients with Sjögren's syndrome }\end{array}$} & \multirow[t]{2}{*}{ Cholinergic agonist } & \multirow[t]{2}{*}{1992} & \multirow[t]{2}{*}{1998} & $\mathrm{RCT}$ & 256 & $\begin{array}{l}\text { mean } 57 \text { years } \\
(24-85)\end{array}$ & 12 weeks & $\begin{array}{l}\text { Global improvement of } \\
\text { dry mouth }\end{array}$ & \multirow[t]{2}{*}[26]{} \\
\hline & & & & & $\mathrm{RCT}$ & 373 & $\begin{array}{l}\text { mean } 55 \text { years } \\
(21-84)\end{array}$ & 12 weeks & $\begin{array}{l}\text { Global improvement of } \\
\text { dry mouth }\end{array}$ & \\
\hline Etanercept & $\begin{array}{l}\text { Reduction in signs and symptoms } \\
\text { of moderately to severely active } \\
\text { polyarticular-course juvenile } \\
\text { rheumatoid arthritis in patients } \\
\text { who have had an inadequate } \\
\text { response to one or more disease- } \\
\text { modifying anti-rheumatic drugs }\end{array}$ & $\begin{array}{l}\text { Tumor necrosis } \\
\text { factor-alpha } \\
\text { inhibitor }\end{array}$ & 1998 & 1999 & $\mathrm{RCT}$ & 69 & $2-17$ years & 7 months & $\begin{array}{l}\text { JIA definition of } \\
\text { improvement criteria }\end{array}$ & {$[10]$} \\
\hline $\begin{array}{l}\text { Dexamethasone } \\
\text { (intravitreal implant) }\end{array}$ & $\begin{array}{l}\text { Treatment of non-infectious uveitis } \\
\text { affecting the posterior segment of } \\
\text { the eye }\end{array}$ & Glucocorticoid & 1998 & 2010 & $\mathrm{RCT}$ & 153 & $\mathrm{n} / \mathrm{a}$ & 8 weeks & $\begin{array}{l}\text { Vitreous haze score and } \\
\text { 3-line improvement from } \\
\text { baseline in best corrected } \\
\text { visual acuity }\end{array}$ & {$[27]$} \\
\hline \multirow[t]{2}{*}{$\begin{array}{l}\text { Fluocinolone acetonide } \\
\text { (intravitreal implant) }\end{array}$} & \multirow[t]{2}{*}{$\begin{array}{l}\text { Treatment of chronic non-infectious } \\
\text { uveitis affecting the posterior segment } \\
\text { of the eye }\end{array}$} & \multirow[t]{2}{*}{ Glucocorticoid } & \multirow[t]{2}{*}{2000} & \multirow[t]{2}{*}{2005} & RCT & 108 & $\mathrm{n} / \mathrm{a}$ & 3 years & $\begin{array}{l}\text { Rate of recurrence of uveitis } \\
\text { affecting the posterior } \\
\text { segment of the study eye }\end{array}$ & \multirow[t]{2}{*}[28]{} \\
\hline & & & & & $\mathrm{RCT}$ & 116 & $\mathrm{n} / \mathrm{a}$ & 3 years & $\begin{array}{l}\text { Rate of recurrence of } \\
\text { uveitis affecting the } \\
\text { posterior segment of the } \\
\text { study eye }\end{array}$ & \\
\hline \multirow[t]{2}{*}{ Meloxicam } & \multirow{2}{*}{$\begin{array}{l}\text { For relief of the signs and symptoms } \\
\text { of pauciarticular or polyarticular course } \\
\text { juvenile rheumatoid arthritis in } \\
\text { patients } 2 \text { years of age or older }\end{array}$} & \multirow[t]{2}{*}{ NSAID } & \multirow[t]{2}{*}{2002} & \multirow[t]{2}{*}{2005} & $\mathrm{RCT}$ & $\mathrm{n} / \mathrm{a}$ & $\geq 2$ years & 12 weeks & ACR Pediatric 30 & \multirow[t]{2}{*}{ [29] } \\
\hline & & & & & $\mathrm{RCT}$ & $\mathrm{n} / \mathrm{a}$ & $\geq 2$ years & 12 weeks & ACR Pediatric 30 & \\
\hline Rilonacept & $\begin{array}{l}\text { Treatment of cryopyrin-associated } \\
\text { periodic syndromes }\end{array}$ & Interleukin inhibitor & 2004 & 2008 & RCT & 47 & $\mathrm{n} / \mathrm{a}$ & 24 weeks & CAPS symptom score & {$[30]$} \\
\hline \multirow[t]{2}{*}{ Adalimumab } & \multirow{2}{*}{$\begin{array}{l}\text { Treatment of juvenile idiopathic } \\
\text { arthritis }\end{array}$} & \multirow{2}{*}{$\begin{array}{l}\text { Tumor necrosis } \\
\text { factor-alpha } \\
\text { inhibitor }\end{array}$} & \multirow[t]{2}{*}{2005} & \multirow[t]{2}{*}{2008} & RCT & 171 & $4-17$ years & 32 weeks & ACR Pediatric 30 & \multirow[t]{2}{*}{ [31] } \\
\hline & & & & & $\mathrm{OL}$ & 32 & $\begin{array}{l}2-\leq 4 \text { years or } \geq \\
4 \text { years weighing } \\
<15 \mathrm{~kg}\end{array}$ & 120 weeks & Safety & \\
\hline Rituximab & $\begin{array}{l}\text { For the use in combination with } \\
\text { glucocorticoids for the treatment } \\
\text { of patients with Wegener's } \\
\text { granulomatosis and microscopic } \\
\text { polyangiitis }\end{array}$ & $\begin{array}{l}\text { Selective } \\
\text { immunosuppressant }\end{array}$ & 2006 & 2011 & $\mathrm{RCT}$ & 197 & $\geq 15$ years & 18 months & $\begin{array}{l}\text { Birmingham Vasculitis Activity } \\
\text { Score for Granulomatosis } \\
\text { with Polyangiitis }\end{array}$ & [16] \\
\hline \multirow[t]{3}{*}{ Colchicine } & \multirow{3}{*}{$\begin{array}{l}\text { Treatment of familial Mediterranean } \\
\text { fever }\end{array}$} & \multirow[t]{3}{*}{ Mitotic poison } & \multirow[t]{3}{*}{2007} & 2009 & Evidenc & ce for $t$ & the efficacy was der & ived from the & e published literature. & {$[32]$} \\
\hline & & & & & $\mathrm{RCT}$ & 15 & $\mathrm{n} / \mathrm{a}$ & $\mathrm{n} / \mathrm{a}$ & $\mathrm{n} / \mathrm{a}$ & \\
\hline & & & & & RCT & 22 & $\mathrm{n} / \mathrm{a}$ & $\mathrm{n} / \mathrm{a}$ & n/a & \\
\hline
\end{tabular}


Table 2 Orphan drugs for the treatment of rare rheumatologic disorders approved by the FDA between 1983 and 2013 (Continued)

\begin{tabular}{|c|c|c|c|c|c|c|c|c|c|c|}
\hline \multirow[t]{2}{*}{ Canakinumab } & \multirow[t]{2}{*}{$\begin{array}{l}\text { Treatment of cryopyrin-associated } \\
\text { periodic syndromes, in adults and } \\
\text { children } 4 \text { years of age and older }\end{array}$} & \multirow[t]{2}{*}{ Interleukin inhibitor } & \multirow[t]{2}{*}{2007} & \multirow[t]{2}{*}{2009} & $\mathrm{RCT}$ & 31 & $9-74$ years & 8 weeks & $\begin{array}{l}\text { Minimal or better for physician's } \\
\text { assessment of disease activity, } \\
\text { assessment of skin disease, } \\
\text { and serum levels of C-Reactive } \\
\text { Protein and Serum Amyloid A }\end{array}$ & \multirow[t]{2}{*}{ [19] } \\
\hline & & & & & $\mathrm{OL}$ & $\mathrm{n} / \mathrm{a}$ & $4-74$ years & & $\mathrm{n} / \mathrm{a}$ & \\
\hline \multirow[t]{2}{*}{ Canakinumab } & \multirow{2}{*}{$\begin{array}{l}\text { Treatment of active systemic } \\
\text { juvenile idiopathic arthritis in } \\
\text { patients aged } 2 \text { through } 16 \text { years }\end{array}$} & \multirow[t]{2}{*}{ Interleukin inhibitor } & \multirow[t]{2}{*}{2008} & \multirow[t]{2}{*}{2013} & $\mathrm{RCT}$ & 84 & $\begin{array}{l}\text { mean } 8.5 \text { years } \\
(2-20)\end{array}$ & 4 weeks & $\begin{array}{l}\text { Adapted ACR Pediatric } 30 \\
\text { and absence of fever }\end{array}$ & \multirow[t]{2}{*}[19]{} \\
\hline & & & & & $\mathrm{RCT}$ & 177 & $\begin{array}{l}\text { mean } 8.5 \text { years } \\
(2-20)\end{array}$ & $\mathrm{n} / \mathrm{a}$ & ACR Pediatric 30 & \\
\hline \multirow[t]{2}{*}{$\begin{array}{l}\text { Difluprednate } \\
\text { (ophthalmic solution) }\end{array}$} & \multirow[t]{2}{*}{$\begin{array}{l}\text { Treatment of endogenous } \\
\text { anterior uveitis }\end{array}$} & \multirow[t]{2}{*}{ Glucocorticoid } & \multirow[t]{2}{*}{2008} & \multirow[t]{2}{*}{2012} & $\mathrm{RCT}$ & 110 & $\mathrm{n} / \mathrm{a}$ & 2 weeks & $\begin{array}{l}\text { Difference in anterior } \\
\text { chamber cell grade }\end{array}$ & \multirow[t]{2}{*}{ [33] } \\
\hline & & & & & $\mathrm{RCT}$ & 90 & $\mathrm{n} / \mathrm{a}$ & 2 weeks & $\begin{array}{l}\text { Difference in anterior } \\
\text { chamber cell grade }\end{array}$ & \\
\hline Anakinra & $\begin{array}{l}\text { Treatment of neonatal-onset } \\
\text { multisystem inflammatory disease }\end{array}$ & Interleukin inhibitor & 2010 & 2012 & $\mathrm{OL}$ & 43 & $0.7-46$ years & 60 months & $\begin{array}{l}\text { disease-specific Diary } \\
\text { Symptom Sum Score }\end{array}$ & [34] \\
\hline Tocilizumab & $\begin{array}{l}\text { Treatment of active polyarticular } \\
\text { juvenile idiopathic arthritis in } \\
\text { patients } 2 \text { through } 16 \text { years of age }\end{array}$ & Interleukin inhibitor & 2012 & 2013 & $\mathrm{RCT}$ & 188 & $2-17$ years & 24 weeks & JIA ACR 30 flare & {$[20]$} \\
\hline
\end{tabular}

ACR Pediatric 30 American College of Rheumatology Pediatric 30 response, CAPS Cryopyrin-associated periodic syndromes, JIA Juvenile idiopathic arthritis, JIA ACR 30 flare Juvenile idiopathic arthritis American College of Rheumatology 30 flare, JRA Juvenile rheumatoid arthritis, n/a not applicable or no information is provided in the FDA label, NSAID Nonsteroidal anti-inflammatory drugs, OL Open label, RCT Randomized controlled of Rheumatology 30 flare, JRA Juvenile rheumatoid arthritis,
trial, uncontrolled, SJIA Systemic juvenile idiopathic arthritis 

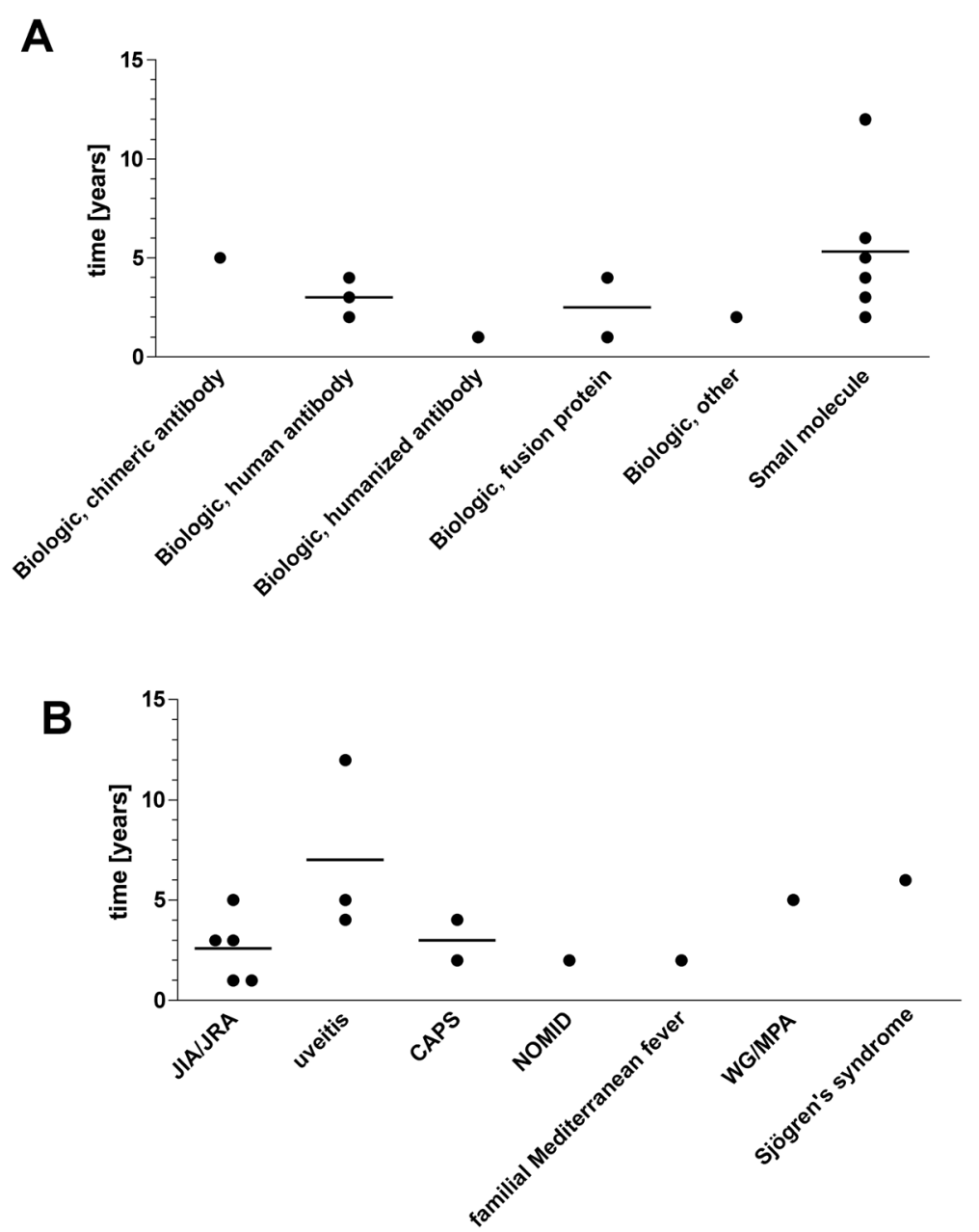

Fig. 3 Orphan drugs for rare rheumatologic disorders - time to FDA approval. a by drug class. b by disease. Lines indicate means

value for the clinician as it may protect patients from unnecessary exposure to further research and should be made publically available.

By definition, drug development in orphan diseases is challenged by small sample sizes [5]. In addition, disease-specific factors, such as the prevalence, disease class, and scientific output, influence success rates in orphan drug development [14]. Rheumatologic diseases include complex pathomechanisms which complicates identification of potential drug targets. Most of the designated compounds target autoimmune and subsequent inflammatory reactions. Particularly, immunomodulators play a pivotal role in disease modification by modulating various pathophysiologically relevant targets in the inflammatory process e.g., antibodies against specific surface antigens on lymphocytes, glucocorticoids that inhibit transcription of inflammatory cytokines such as interleukins and TNF-alpha, decoy receptors, or antagonists for receptors of inflammatory proteins. In addition, compounds that relieve symptoms associated with rheumatologic diseases were designated as orphan drugs, such as pilocarpine- $\mathrm{HCl}$ which increases lacrimal secretion and hence alleviates xerostomia and keratoconjunctivitis sicca in Sjögren's syndrome patients. Nitric oxide (NO), a biomarker of airway inflammation, received orphan drug designation for the diagnosis of sarcoidosis. However, the diagnostic clinical trial could not detect a difference in exhaled NO levels between patients and controls [15]. All remaining 76 orphan drug designations for rheumatologic conditions were of therapeutic purpose.

Orphan drugs for rheumatologic disease hold indications in other disease areas by targeting pathways also relevant in other conditions. For example, rituximab, which is a selective immunosuppressant targeting CD20 surface proteins on B-lymphocytes, is also approved for treatment of Non-Hodgkin's Lymphoma and Chronic Lymphocytic Leukemia [16]. In contrast, orphan drugs for lysosomal storage disorders target a specific pathway that is unique for the respective conditions. For instance, although Fabry 
Table 3 Withdrawn orphan drug designations between 1983 and 2013 for compounds intended to treat rare rheumatologic disorders

\begin{tabular}{|c|c|c|}
\hline Withrawn compound & Designation year & Designated indication according to FDA database \\
\hline Dimethyl sulfoxide & 1986 & Cutaneous manifestations of scleroderma \\
\hline Guanethidine monosulfate & 1986 & Moderate to severe reflex sympathetic dystrophy and causalgia \\
\hline Bromhexine & 1989 & $\begin{array}{l}\text { Mild to moderate keratoconjunctivitis sicca in patients with } \\
\text { Sjögren's syndrome }\end{array}$ \\
\hline Immune globulin intravenous (human) & 1992 & Juvenile rheumatoid arthritis \\
\hline Immune globulin intravenous (human) & 1992 & Polymyositis/dermatomyositis \\
\hline Al-RSA & 1992 & Autoimmune uveitis \\
\hline Methotrexate & 1993 & Juvenile rheumatoid arthritis \\
\hline Dehydroepiandrosterone & 1994 & $\begin{array}{l}\text { Systemic lupus erythematosus (SLE) and the reduction in the use } \\
\text { of steroids in steroid-dependent SLE patients }\end{array}$ \\
\hline Interferon beta-1a & 1998 & Juvenile rheumatoid arthritis \\
\hline Humanized MAb (IDEC-131) to CD40L & 1999 & Systemic lupus erythematosus \\
\hline Etanercept & 1999 & Wegener's granulomatosis \\
\hline pVGI.1 (VEGF2) & 1999 & Thromboangiitis obliterans \\
\hline Infliximab & 2003 & Giant cell arteritis \\
\hline $\begin{array}{l}\text { Human Anti-tumor Necrosis factor alpha } \\
\text { monoclonal antibody }\end{array}$ & 2003 & $\begin{array}{l}\text { Uveitis of the posterior segment of non-infectious etiology, and } \\
\text { uveitis of the anterior segment of non-infectious etiology and } \\
\text { refractory to conventional therapy }\end{array}$ \\
\hline Golimumab & 2004 & Chronic sarcoidosis \\
\hline
\end{tabular}

disease and Gaucher disease are sphingolipidoses, the therapeutic enzyme for Fabry disease (agalsidase alfa or beta) is different to the enzyme replacement therapy in Gaucher disease (recombinant glucocerebrosidase) $[17,18]$.

The choice for or against an orphan drug development pathway can vary within same disease entity: both tocilizumab and canakinumab are approved for the treatment of systemic juvenile idiopathic arthritis. Of interest, the orphan program with canakinumab consisted of two studies with $N=261$ participants followed for 4 and 48 weeks, whereas the non-orphan tocilizumab program had only one clinical trial and involved $N=112$ subjects with a study duration of 12 weeks $[19,20]$. Sample size and design of pivotal clinical trials for the approved rheumatologic orphan drug indication varied. Most studies were randomized placebo controlled trials which corroborates that drug development in rare diseases is possible at a high level of evidence. The FDA guidance for industry for the development of drug products for the treatment of rheumatoid arthritis recommends the use of efficacy endpoints capturing clinical remission and prevention of structural damage, suggests to limit the use of placebo both in short-term and long-term trials, and encourages study designs with active comparators [21]. Endpoints in clinical trials of the orphan drugs approved for rheumatologic disorders included categorical variables such as number of attacks in familial Mediterranean fever under colchicine, rate of recurrence of uveitis under fluocinolone acetonid intravitreal implant, disease scores such as vitreous haze score or anterior chamber cell grade for uveitis under difluprednate ophthalmic emulsion or dexamethasone intravitreal implant, multisystem composite disease scores, such as the Birmingham Vasculitis Activity Score for Granulomatosis with Polyangiitis [22] or the American College of Rheumatology Pediatric 30 criteria for improvement which comprises subjective, objective and biochemical components [23]. For the future, it would be desirable to capture the impact of the tested intervention on patients' needs by including patient centered outcome measures such as the Canadian Occupational Performance Measure as clinical trial endpoints where possible [24]. As signals may not become evident or may not be detectable in the initial small and short clinical trials (Table 2), it is desirable to followup on the long-term effectiveness and safety outcome in systematic disease registries after drug approval. Compared to oncological orphan drugs with a shorter time to approval, orphan drug designations in rheumatologic diseases seem to be either set earlier in the drug development process or the process from designation to approval may be slower [12]. In general, orphan drug designations are granted during the final steps of the drug development process [25]. Although, the orphan drug designation is arbitrary in the drug development process, time to approval allows an approximate estimation of orphan drug approvals of currently filed designated orphan drugs.

This quantitative analysis has several limitations. We made the assumption that the designation of a compound 
as an orphan drug was considered a surrogate for the intent to develop a drug for a disease. However, not all manufacturers may seek orphan drug designation by the FDA and information may therefore not be transparent, e.g. due to patent considerations. The amount of designations might be prone to bias since one compound might be designated as an orphan drug several times, e.g. interleukin 1-trap and rilonacept. The true duration of the development program may not be reflected by time to approval because the time of orphan designation may be arbitrary in the drug development process and, thus does not allowing a comparison between orphan drug development and non-orphan drug development. Data from the European Medicine Agency data were not formally analyzed. We chose this approach, because the European orphan legislation was only introduced in 2000. Therefore, the European database is less comprehensive compared to the one hosted by the FDA. However, drug development for orphan conditions is a global effort. EMA orphan drug designations show similar trends (data not shown). Therefore, the present formal analysis of the FDA data and their impact for patients around the world are considered generalizable.

\section{Conclusions}

In conclusion, orphan drug development is challenging: 30 years of US orphan drug act delivered 14 orphan drug programs with anti-rheumatic or supportive compounds for six rare rheumatologic conditions. Although, rarity and diversity of conditions account for the small sizes all but one pivotal study were randomized controlled trials.

\section{Abbreviations}

ANCA: anti-neutrophil cytoplasmic antibody; CAPS: cryopyrin-associated periodic syndromes; CINCA: chronic infantile neurologic cutaneous and articular syndrome; CREST syndrome: calcinosis, Raynaud's phenomenon, esophageal dysmotility, sclerodactyly, and telangiectasia; DNA: desoxyribonucleic acid; FCAS: familial cold autoinflammatory syndrome; FDA: Food and Drug Administration; IgA: immunglobulin A; IgD: immunglobulin D; JIA: juvenile idiopathic arthritis; MWS: Muckle-Wells Syndrome; NO: nitric oxide; NOMID: neonatal-onset multisystem inflammatory disease; NSAID: nonsteroidal anti-inflammatory drug; PFAPA syndrome: periodic fever, aphthous stomatitis, pharyngitis, adenitis; TRAPS: tumor necrosis factor receptor associated periodic syndrome; VEGF2: vascular endothelial growth factor 2.
}

\section{Competing interests}

AL received a personal scholarship from the "Dr. August and Dr. Anni Lesmüller foundation". MR received consultancy fees or research grants from Alexion, GSK, Oxyrane and Shire. TL and GFH report not conflict of interest.

\section{Authors' contributions}

TL has contributed to the acquisition, analysis, and interpretation of the data, critical revision of the manuscript for important intellectual content, and material support. AL has contributed to the acquisition, analysis, and interpretation of the data, drafting of the manuscript, critical revision of the manuscript for important intellectual content, and statistical analysis. GFH contributed to the interpretation of the data, critical revision of the manuscript for important intellectual content, and material support. MR has conceptualized the design of the study, contributed to the acquisition, analysis, and interpretation of the data, drafting of the manuscript, critical revision of the manuscript for important intellectual content, and statistical analysis. All authors approved the final version to be published and agreed to be accountable for all aspects of the work in ensuring that questions related to the accuracy or integrity of any part of the work are appropriately investigated and resolved. All authors confirm that they had full access to all the data in the study and had final responsibility for the decision to submit for publication.

\section{Author details}

${ }^{1}$ Center for Pediatric and Adolescent Medicine/Pediatric Rheumatology, and Center for Rare Diseases, Heidelberg University Hospital, Im Neuenheimer Feld 430, 69120 Heidelberg, Germany. ${ }^{2}$ Department of Clinical Pharmacology and Pharmacoepidemiology, Heidelberg University Hospital, Im Neuenheimer Feld 410, 69120 Heidelberg, Germany. ${ }^{3}$ Cooperation Unit Clinical Pharmacy, Heidelberg University Hospital, Im Neuenheimer Feld 410, 69120 Heidelberg, Germany. ${ }^{4}$ Center for Pediatric and Adolescent Medicine/ Pediatric Neurology and Metabolic Medicine, Center for Rare Disorders, Heidelberg University Hospital, Im Neuenheimer Feld 430, D-69120 Heidelberg, Germany.

Received: 2 November 2015 Accepted: 28 April 2016

Published online: 12 May 2016

\section{References}

1. Prevalence of rare diseases: Bibliographic data », Orphanet Report Series, Rare Diseases collection, July 2015,Number 1: Diseases listed in alphabetical order. http://www.orpha.net/orphacom/cahiers/docs/GB/Prevalence_of_ rare_diseases_by_alphabetical_list.pdf. Accessed 20 October 2015

2. Schieppati A, Henter JI, Daina E, Aperia A. Why rare diseases are an important medical and social issue. Lancet. 2008;371:2039-41.

3. Thierry S, Fautrel B, Lemelle I, Guillemin F. Prevalence and incidence of juvenile idiopathic arthritis: a systematic review. Joint Bone Spine. 2014;81:112-7.

4. Haffner ME, Torrent-Farnell J, Maher PD. Does orphan drug legislation really answer the needs of patients? Lancet. 2008;371:2041-4.

5. Buckley BM. Clinical trials of orphan medicines. Lancet. 2008;371:2051-5.

6. FDA. Search Orphan Drug Designations and Approvals. http://www. accessdata.fda.gov/scripts/opdlisting/oopd/index.cfm. Accessed 22 July 2014

7. Minden K, Niewerth M, Listing J, Zink A, German Study Group of Pediatric R. Health care provision in pediatric rheumatology in Germany-national rheumatologic database. J Rheumatol. 2002;29:622-8.

8. Stanczyk J, Ospelt C, Gay S. Is there a future for small molecule drugs in the treatment of rheumatic diseases? Curr Opin Rheumatol. 2008;20:257-62.

9. Rak Tkaczuk KH, Jacobs IA. Biosimilars in oncology: from development to clinical practice. Semin Oncol. 2014;41 Suppl 3:S3-12.

10. FDA. ENBREL, BLA no. 103795, label. http://www.accessdata.fda.gov/ drugsatfda_docs/label/2015/103795s5548lbl.pdf. Accessed 20 October 2015

11. Stone $J H$, Holbrook JT, Marriott MA, Tibbs AK, Sejismundo LP, Min Yl, et al. Solid malignancies among patients in the Wegener's Granulomatosis Etanercept Trial. Arthritis Rheum. 2006;54:1608-18.

12. Stockklausner C, Lampert A, Hoffmann GF, Ries M. Novel Treatments For Rare Cancers: The U.S. Orphan Drug Act Is Delivering - A Cross-Sectional Analysis. Oncologist 2016;21(4):487-93.

13. Heemstra HE, Leufkens HG, Rodgers RP, Xu K, Voordouw BC, Braun MM. Characteristics of orphan drug applications that fail to achieve marketing approval in the USA. Drug Discov Today. 2011;16:73-80.

14. Heemstra HE, van Weely S, Büller HA, Leufkens HG, de Vrueh RL. Translation of rare disease research into orphan drug development: disease matters. Drug Discov Today. 2009;14:1166-73.

15. Wilsher ML, Fergusson W, Milne D, Wells AU. Exhaled nitric oxide in sarcoidosis. Thorax. 2005;60:967-70.

16. FDA. RITUXAN, BLA no. 103705, label. http://www.accessdata.fda.gov/ drugsatfda_docs/label/2013/103705s5414lbl.pdf. Accessed 20 October 2015

17. Mechler K, Mountford WK, Hoffmann GF, Ries M. "Pressure for drug development in lysosomal storage disorders - a quantitative analysis thirty years beyond the US orphan drug act. Orphanet J Rare Dis. 2015 Apr 18.

18. Brady RO. Enzyme replacement therapy: conception, chaos and culmination. Philos Trans R Soc Lond B Biol Sci. 2003;358:915-9.

19. FDA. ILARIS, BLA no. 125319, label. http://www.accessdata.fda.gov/ drugsatfda_docs/label/2013/125319s062lbl.pdf. Accessed 20 October 2015 
20. FDA. ACTEMRA, BLA no. 125276, label http://www.accessdata.fda.gov/ drugsatfda_docs/label/2013/125276s092lbl.pdf. Accessed 20 October 2015

21. FDA. Guidance for Industry Rheumatoid Arthritis: Developing Drug Products for Treatment. http://www.fdanews.com/ext/resources/files/archives/6281301/06-07-13-RA.pdf. Accessed 20 October 2015

22. Stone JH, Hoffman GS, Merkel PA, Min Yl, Uhlfelder ML, Hellmann DB, et al. A disease-specific activity index for Wegener's granulomatosis: modification of the Birmingham Vasculitis Activity Score. International Network for the Study of the Systemic Vasculitides (INSSYS). Arthritis Rheum. 2001;44:912-20.

23. Giannini EH, Ruperto N, Ravelli A, Lovell DJ, Felson DT, Martini A.

Preliminary definition of improvement in juvenile arthritis. Arthritis Rheum. 1997;40:1202-9.

24. van de Ven-Stevens LA, Graff MJ, Selles RW, Schreuders TA, van der Linde H, Spauwen PH, Geurts AC. Instruments for assessment of impairments and activity limitations in patients with hand conditions: A European Delphi study. J Rehabil Med. 2016;47:948-56.

25. Field MJ, Boat TF. Rare diseases and orphan products: Accelerating research and development. Washington: National Press (US); 2010.

26. FDA. SALAGEN, NDA no. 020237, label. http://www.accessdata.fda.gov/ drugsatfda_docs/label/2003/020237s012lbl.pdf. Accessed 20 October 2015

27. FDA. OZURDEX, NDA no. 022315, label. http://www.accessdata.fda.gov/ drugsatfda_docs/label/2014/022315s009lbl.pdf. Accessed 20 October 2015

28. FDA. RETISERT, NDA no. 021737, label http://www.accessdata.fda.gov/ drugsatfda docs/label/2011/021737s019.pdf. Accessed 20 October 2015

29. FDA. MOBIC, NDA no. 020938, label. http://www.accessdata.fda.gov/ drugsatfda docs/label/2012/020938s022lbl.pdf. Accessed 20 October 2015

30. FDA. ARCALYST, BLA no. 125249, label. http://www.accessdata.fda.gov/ drugsatfda_docs/label/2008/125249lbl.pdf. Accessed 20 October 2015

31. FDA. HUMIRA, BLA no. 125057, label. http://www.accessdata.fda.gov/ drugsatfda_docs/label/2014/125057s367lbl.pdf. Accessed 20 October 2015

32. FDA. COLCRYS, NDA no. 022351, label. http://www.accessdata.fda.gov/ drugsatfda_docs/label/2009/022351 lbl.pdf. Accessed 20 October 2015

33. FDA. DUREZOL, NDA no. 022212, label. http://www.accessdata.fda.gov/ drugsatfda_docs/label/2013/022212s012lbl.pdf. Accessed 20 October 2015

34. FDA. KINERET, BLA no. 103950, label. http://www.accessdata.fda.gov/ drugsatfda_docs/label/2013/103950s5150lbl.pdf. Accessed 20 October 2015

\section{Submit your next manuscript to BioMed Central and we will help you at every step:}

- We accept pre-submission inquiries

- Our selector tool helps you to find the most relevant journal

- We provide round the clock customer support

- Convenient online submission

- Thorough peer review

- Inclusion in PubMed and all major indexing services

- Maximum visibility for your research

Submit your manuscript at www.biomedcentral.com/submit

C Biomed Central 